\title{
Antioxidant and Antibacterial Assay Against Fish Pathogen Bacteria of Kjellbergiodendron celebicum (Koord.) Merr. Leaf Extract
}

\author{
Bianca Priscilia ${ }^{1}$, Media Fitri Isma Nugrahaa ${ }^{2, *}$, Hessy Novita ${ }^{3}$, Berna Elya ${ }^{1}$
}

Bianca Priscilia ${ }^{1}$, Media Fitri Isma Nugraha $^{2, *}$, Hessy Novita ${ }^{3}$, Berna Elya $^{1}$

${ }^{1}$ Faculty of Pharmacy, University of Indonesia, Depok 16424 West Java, INDONESIA.

${ }^{2}$ Indonesian Research Institute for Ornamental Fish Culture - the Ministry Marine and Fisheries, J. Perikanan No 13 Pancoran Mas Depok 16438 PO BOX 06 West Java INDONESIA.

${ }^{3}$ Installation Pathology and Fish Disease Ministry Marine and Fisheries. JI Perikanan No 13 A Pancoran Mas Depok West Java INDONESIA.

\section{Correspondence}

\section{Media Fitri Isma Nugraha}

Indonesian Research Institute for

Ornamental Fish Culture - the Ministry

Marine and Fisheries, JI. Perikanan No 13

Pancoran Mas Depok 16438 PO BOX 06

West Java INDONESIA.

E-mail: media.nugraha@kkp.go.id; mfitri_ isman@yahoo.com

History

- Submission Date: 19-10-2019;

- Review completed: 29-10-2019;

- Accepted Date: 25-11-2019.

DOI : 10.5530/pj.2020.12.26

Article Available online http://www.phcogj.com/v12/i1

Copyright

(C) 2020 Phcogj.Com. This is an open access article distributed under the terms of the Creative Commons Attribution 4.0 International license.

\begin{abstract}
Introduction: Kjellbergiodendron celebicum (Koord.) Merr. (local name: tombe uwa) is a plant endemic to Sulawesi, Indonesia, and grows around lakes or aquatic environments where fish live. Based on phytochemical screening in previous studies, i.e. methanol extract and ethyl acetate fraction from the leaves of Kjellbergiodendron celebicum (Koord.) Merr., the methanol extract gives positive results containing polyphenol compounds in the flavonoid group which have been known to have strong antioxidant and antibacterial properties. Objective: To test the effectiveness of the comparison of the natural content in the compounds (antibacterial and antioxidant properties) and the total content of phenol in Kjellbergiodendron celebicum (Koord.) Merr., which was extracted using two methods, i.e. maceration and UltrasonicAssisted Extraction (UAE), in fish-disease bacteria. Method: The leaves were separated to be extracted with two different methods: maceration and Ultrasound-Assisted Extraction (UAE). Extracts were first screened qualitatively for antioxidant activity and then quantified with respect to in vitro antioxidant activity using the 2.2-diphenyl-1-picrylhydrazyl (DPPH) radical scavenging assay and the ferric-reducing antioxidant power (FRAP) assay. Antibacterial activity was determined by the paper disc diffusion method and microdilution. Results: $70 \%$ Ethanol in leaves extract of Kjellbergiodendron celebicum (Koord.) Merr. The extract which has the highest activity based on the DPPH test and FRAP test is the extract from UAE extraction with $I C_{50}$ value of $9.81512 \mu \mathrm{g} / \mathrm{mL}$ and ferrous equivalent antioxidant capacity (FeEAC) value of $1.661 .3 \mu \mathrm{mol} / \mathrm{gr}$. UAE method also has a higher potential in antibacterial activity based on the diffusion method of paper discs and microdilution with the MIC obtained as much as 390.6 $\mu \mathrm{g} / \mathrm{mL}$. Conclusion: the UAE extraction method is better at scanning polyphenol compounds compared to the conventional maceration extraction method. Therefore, the results of the antioxidant and antibacterial activity using the UAE method are better than the maceration method.
\end{abstract}

Key words: Aeromonas hydrophila, Edwardsiella ictaluri, Flavobacterium columnare, Maceration, Phytochemical compound, Ultrasonic-Assisted Extraction.

\section{INTRODUCTION}

A number of diseases that attack fish are caused by bacterial infections. Pathogenic bacteria work by infecting the organism so that abnormal symptoms appear as signs of a disease. Infection by pathogenic bacteria is treated with antibiotics. However, the use of antibiotics can cause resistant bacteria to appear if not given with the right dose and timing. The use of secondary metabolites from plants is another option to overcome this. Fish health is also influenced by contaminants in the environment where the fish live. Contaminants such as metal ions or heavy metals are involved in the occurrence of oxidative stress in fish. Oxidative stress is a condition in which the production of Reactive Oxygen Species (ROS) and antioxidant defences from the body of living organisms are not balanced. These conditions can damage DNA, RNA, protein, and fat. ROS is known to be induced by substances, such as metal ions, pesticides, and petroleum pollutants. ${ }^{1}$ As in humans, increasing ROS production in fish can cause protein and lipid oxidation, changes in gene expression, and other damage. ${ }^{2}$ Preventing oxidative stress can be done by adding antioxidants from outside the body. Natural antioxidants are currently in great demand, such as phenolic or polyphenolic compounds, which are compounds from plants with strong antioxidant capacity $^{3}$ that can reduce free radicals, prevent cellular damage due to oxidative stress, and reduce the risk of chronic diseases. Kjellbergiodendron celebicum (Koord.) Merr. (tombe uwa) is a plant from Sulawesi, Indonesia, and grows around lakes or aquatic environments where fish live. ${ }^{4}$ Based on phytochemical screening in previous studies, ethyl acetate fraction from the leaves of Kjellbergiodendron celebicum (Koord.) Merr., the methanol extract gives positive results containing polyphenol compounds in the flavonoid group which have been known to have strong antioxidant and antibacterial properties. This study attempts to find alternative plants that grow in environments close to fish, which contain natural compounds that have antibacterial and antioxidant properties and count the total phenolic content of $70 \%$ ethanol extract of leaves of Kjellbergiodendron

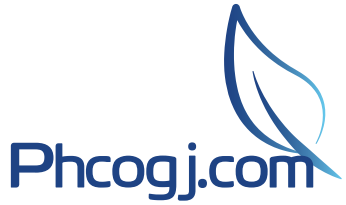

Cite this article: Priscilia B, Nugraha MFI, Novita H, Elya B. Antioxidant and Antibacterial Assay Against Fish Pathogen Bacteria of Kjellbergiodendron celebicum (Koord.) Merr. Leaf Extract. Pharmacog J. 2020;12(1):173-9. 
celebicum (Koord.) Merr. Plant extraction uses two different methods, namely maceration and Ultrasonic-Assisted Extraction (UAE) to see whether there are differences in extraction results obtained.

\section{MATERIALS AND METHODS}

\section{Chemicals}

Standards used were ascorbic acid (Sigma-Aldrich, A5960; city, state [abbreviation], USA), quercetin (Sigma-Aldrich, Q4951; city, state [abbreviation], USA), gallic acid (Sigma-Aldrich, USA), and chloramphenicol.

\section{Fish pathogen}

The pathogenic bacteria that will be used in this study are pathogenic isolates Aeromonas hydrophila, Edwardsiella ictaluri, and Flavobacterium columnare, which are the collections of the laboratories for fish disease research and development of the Ministry of Marine and Fisheries of the Republic of Indonesia.

\section{Sample preparation}

The leaves of Kjellbergiodendron celebicum (Koord.) Merr. from Lake Towuti, South Sulawesi, were freshly picked, collected, sorted, and dried (collection and drying were carried out by the Indonesian Research Centre for Ornamental Fish). The leaves were then crushed until they became smaller.

\section{Microscopic observations by scanning electron microscope (SEM) and light microscope}

Microscopic testing of leaf powder Kjellbergiodendron celebicum (Koord.) Merr. using SEM Model: JSM - IT 200 was conducted by the Zoology Field of the Biology Research Centre - Indonesian Institute of Sciences (LIPI), Cibinong, and the observations were also made using a light microscope.

\section{Extraction}

Extraction was done using maceration and Ultrasound-Assisted Extraction (UAE). Simplisia powder extraction was carried out by the maceration method using $70 \%$ ethanol with the ratio of simplisia to solvent 1:10. Extraction was done by soaking the powder for 24 hours in a closed vessel with occasional stirring. This maceration stage was repeated three times. All maceration results were filtered and then collected. Simplicial powder was also extracted using UAE with $70 \%$ solvent ethanol with a ratio of $1: 10$ at $50^{\circ} \mathrm{C}$. Both extracted results from maceration and UAE were evaporated with a rotary vacuum evaporator and water bath at $50^{\circ} \mathrm{C}$. Calculation of the extraction yield was carried out by dividing the thick extract with the initial simplicial weight (grams), the result of which was expressed in percentage.

Rendement $(\%)=\frac{\text { Weight of extract }}{\text { Weight of simplicia }} \times 100 \%$

\section{Qualitative antioxidant activity test with DPPH solution}

A qualitative test was carried out by spraying DPPH solution into the sample solution which was bottled on the TLC plate and incubated for 30 minutes. The TLC profile in UV rays was observed with a wavelength of $254 \mathrm{~nm}$.

Quantitative antioxidant activity test with the DPPH assay

This assay was carried out using the method of ${ }^{5}$, with minor modifications. The antioxidant activity test was performed on extracts from maceration and UAE (dry matter adjusted to a working solution of $1000 \mu \mathrm{g} / \mathrm{mL}$ in methanol, then diluted to 5 concentrations: $60 ; 80$;
100; 120 ; and $140 \mu \mathrm{g} / \mathrm{mL})$ and standards $(100 \mu \mathrm{g} / \mathrm{mL}$ quercetin stock solution in methanol). The DPPH solution absorption was measured using a UV-Vis spectrophotometer first. A total of $20 \mu \mathrm{L}$ of quercetin solution, negative control or sample, was added with $180 \mu \mathrm{L}$ of DPPH $150 \mathrm{mmol} / \mathrm{L}$ solution. The mixture was shaken for 60 seconds in the well, and then the solution was incubated at room temperature for 40 minutes in dark conditions. ${ }^{5}$ Absorbance of the test solution was measured at the wavelength obtained in the DPPH maximum wavelength test. The percentage of inhibition of extracts against DPPH was calculated by the following formula:

Percentage inhibition $=$

Control absorbance - sample absorbance Control absorbance

After the inhibition percentage of each concentration was obtained, linear regression was made so that the equation $y=a+b x$ was obtained, where $\mathrm{x}$ is the concentration $(\mu \mathrm{g} / \mathrm{mL})$ and $\mathrm{y}$ is the percentage of inhibition (\%). Antioxidant activity is expressed by $50 \%$ Inhibition Concentration or $\mathrm{IC}_{50}$, which is the concentration of the sample which can reduce DPPH radicals by $50 \%$ from the initial concentration.

Quantitative antioxidant activity test with the FRAP assay

This test was based on the microplate reader method described by ${ }^{6}$ with minor modifications, using ammonium ferrous sulphate (AFS) as the standard. Antioxidant activity in the FRAP method was calculated as ferrous equivalent antioxidant capacity (FeEAC) in $\mu \mathrm{moL} / \mathrm{g}$, using the equation:

FeEAC $(\mu \mathrm{mol} / \mathrm{gr})=\frac{\Delta \mathrm{A}}{\mathrm{GRAD}} \times \frac{\mathrm{Av}}{\mathrm{SpV}} \times \mathrm{D} \times \frac{1}{\mathrm{C}} \times 10^{5}$

Where $\Delta \mathrm{A}=$ pathlength correction value, GRAD is the gradient of the AFS calibration curve, Av = aliquot volume $(300 \mu \mathrm{L}), \mathrm{Spv}=$ test sample volume $(20 \mu \mathrm{L}), \mathrm{C}=$ sample concentration, and $\mathrm{D}=1$.

\section{Antibacterial test with the paper disc diffusion method}

In the antibacterial test, bacterial culture and bacterial suspension of Aeromonas hydrophila, Edwardsiella ictaluri, and Flavobacterium columnare were carried out. Chloramphenicol was used as the positive control. $0.2 \mathrm{~g}$ leaf extract of Kjellbergiodendron celebicum (Koord.) Merr. from maceration and UAE was dissolved in a tube with $1 \mathrm{~mL} \mathrm{5 \%}$ DMSO solvent. The Mueller Hinton Agar (MHA) media which already contained the inoculum in the test tube was poured into a Petri dish containing $10 \mathrm{ml}$ of MHA media, then homogenized by shaking, and waited until the media solidified. After sterile paper discs were prepared, the extract was dropped onto the paper discs. Negative control using extract sample solvent, DMSO, was dropped on paper discs by $20 \mu \mathrm{L}$. Positive control of chloramphenicol $30 \mu \mathrm{g} / \mathrm{mL}$ was also placed on the plate agar. The discs were then incubated for 24 hours at $30^{\circ} \mathrm{C}$. The antimicrobial agent diffused into the agar and inhibited the growth of the tested microorganism, and then the diameters of the inhibition growth zones were measured with units of millimetres $(\mathrm{mm})$.

\section{Antibacterial test with the microdilution method}

Each type of bacteria was tested triply using 96-well microplates. A multilevel dilution of extract solution was carried out in 5\% DMSO. Antibiotic control (KB) consisted of $50 \mu \mathrm{L}$ dilution of chloramphenicol antibiotics with a medium and $50 \mu \mathrm{L}$ bacterial suspension was also carried out. The negative controls $(\mathrm{KN})$, media control $(\mathrm{KM})$, and germ control $(\mathrm{KK})$ were also carried out, as well as negative control consisting of $50 \mu \mathrm{L}$ medium and $50 \mu \mathrm{L} 5 \%$ DMSO, KM consisting of 100 $\mu \mathrm{L}$ medium, and $\mathrm{KK}$ consisting of $50 \mu \mathrm{L}$ medium and $50 \mu \mathrm{L}$ bacterial suspension. 
Each microplate was covered with a microplate cover and then incubated at $30^{\circ} \mathrm{C}$ for 24 hours. Bacterial growth could be seen from the turbidity in the well that would be determined using a microplate reader to determine the value of Optical Density (OD) at a wavelength of $600 \mathrm{~nm}$. MIC was determined in units of $\mu \mathrm{g} / \mathrm{mL}$.

\section{Phytochemical screening}

Phytochemical screening was performed in this study to identify the compound classes present in the extract. The compound classes tested for were terpenoid, alkaloid, anthraquinone, flavonoid, tannin, saponin, and glycosides.

\section{Total phenolic content determination}

Total phenolic content in the leaf extracts of Kjellbergiodendron celebicum (Koord.) Merr. was determined by the Folin-Ciocalteau colorimetric method. The microplate used in the TPC method was based on the 96-well microplate the Folin-Ciocalteu method given by with some modifications. A total of $25 \mu \mathrm{L}$ of the sample solution or the standard solution was mixed with $100 \mu \mathrm{L}$ of 1:4 diluted Folin-Ciocalteu reagent and shaken for $60 \mathrm{~s}$ in a 96-well microplate and incubated for 4 minutes. Then the solution was added with $75 \mu \mathrm{L}$ of sodium carbonate solution $(1 \%)$ and shaken for $60 \mathrm{~s}$. The solution was incubated within two hours at room temperature. The absorbance was measured at $\lambda 750$ $\mathrm{nm}$ using a microplate reader 96-well ${ }^{\mathrm{TM}}$ (Versa Max ELISA Microplate Reader, USA). The calibration curve of standards (gallic acid) was measured by the absorbance from the microplate reader instrument and was calculated. The total phenolic content was derived from the calibration curve. The total phenolic contents were expressed as $\mathrm{mg}$ gallic acid equivalents (GAE)/g extract.

\section{RESULTS}

\section{Sample preparation}

600 grams of simplicial powder of Kjellbergiodendron celebicum (Koord.) Merr. leaves were derived from the leaves obtained from Danau Towuti, South Sulawesi, Indonesia. The fresh leaves of Kjellbergiodendron celebicum (Koord.) Merr. were processed by wet sorting and washing to separate impurities. After drying, the simplicial powder was sorted dry to remove the remaining impurities or separate the simplicial powder that does not meet the requirements. The simplicial powder was then pollinated to reduce its size which can enlarge the surface area of simplicia, so that it will facilitate the penetration of solvents during the extraction process, and the extraction of compounds during extraction can give maximum results.

\section{Microscopic observations by scanning electron microscope (SEM) and light microscope}

Microscopic observations of leaf powder Kjellbergiodendron celebicum (Koord.) Merr. were carried out using the Scanning Electron Microscope (SEM) by the Zoology Field of the Biology Research Centre- Indonesia Institute of Science (LIPI), Cibinong, using a light microscope. The use of SEM aims to provide a 3-dimensional picture of the object being observed. The results of the microscopic identification of the dry powder from the simplicial leaf of Kjellbergiodendron celebicum (Koord.) Merr. are shown in Figure 1.

\section{Extraction}

The extraction process of the leaves of Kjellbergiodendron celebicum (Koord.) Merr. was completed using the two methods, i.e. maceration and Ultrasound-Assisted Extraction (UAE). The selection of 2 extraction methods was carried out to see whether there was any correlation between the extraction method and the antioxidant and antibacterial activity. The maceration and UAE methods are extraction

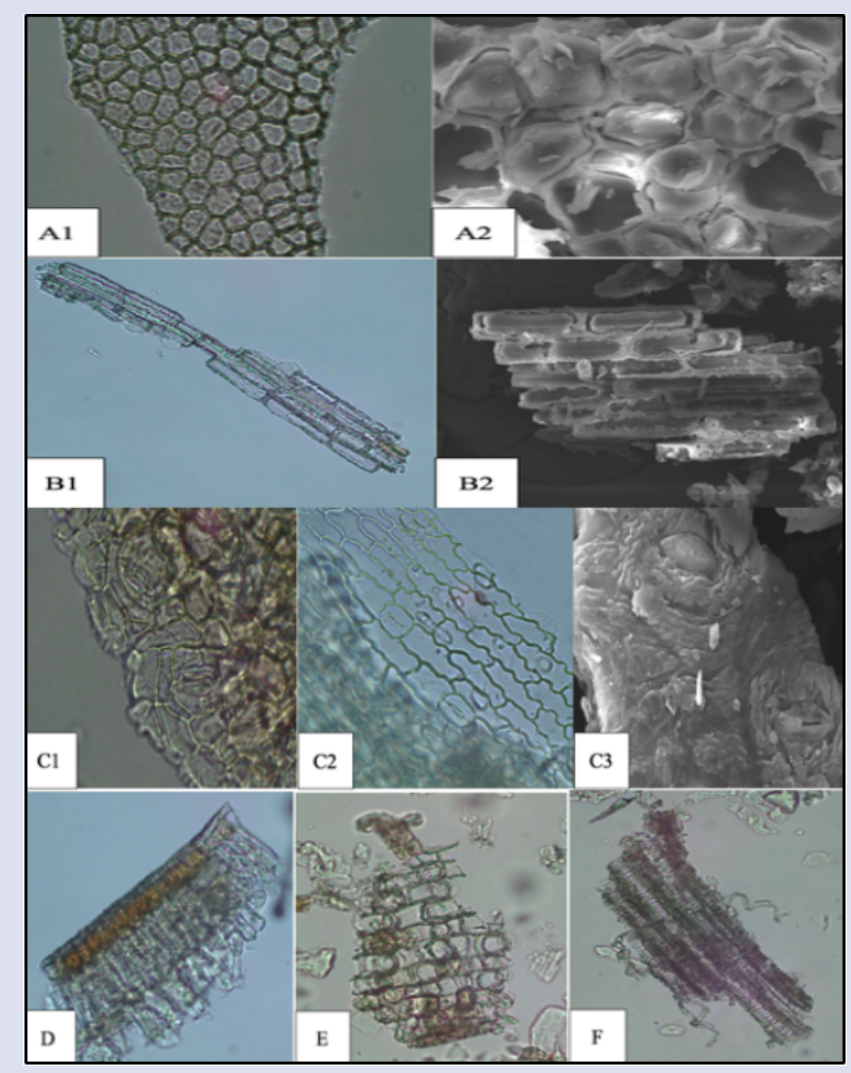

Figure 1: Microscopic identification of leaf powder Kjellbergiodendron celebicum. A: epidermis layer (1) from a light microscope (2) from SEM; $B$ : epidermis layer seen from the surface (1) from a light microscope (2) from SEM; C: stomata type anomocytic (Ranunculaceae) (1) from a light microscope (2) from SEM; D: epidermis layer and palisade layer; E: spongy layer; F: vascular bundle.

methods that are inexpensive and easy to do. In the UAE method, extraction of phenolic components can be carried out at frequencies between $20-60 \mathrm{kHz} .^{7}$ The extraction was carried out using $70 \%$ ethanol. Water and ethanol and their mixtures can be used as solvent fluids in making extracts because they are not toxic. The UAE method of extracting phenolic components uses ethanol with concentrations between $35 \%$ and $70 \%$, which will increase with the increasing ethanol concentration. ${ }^{8}$ The percentage of the yield of $70 \%$ ethanol leaves extract Kjellbergiodendron celebicum (Koord.) Merr. is shown in Table 1.

\section{Qualitative antioxidant activity test with DPPH solution}

The leaf extract of Kjellbergiodendron celebicum (Koord.) Merr. was tested positive for antioxidant activity. Quantification of the antioxidant activity was then determined using both the DPPH and FRAP assay methods.

\section{Quantitative antioxidant activity test with the DPPH assay}

Quercetin has been known to have significant antioxidant activity, so it can be used as a positive control to ensure that the chosen method is valid and can be used. $\mathrm{IC}_{50}$ obtained from the linear regression equation was $2.9758 \mu \mathrm{g} / \mathrm{mL}$. The calibration curve of quercetin for the DPPH antioxidant assay is shown in Tables 2 and 3.

The percentage inhibition of both maceration and UAE extractions can be seen in Table 3. From the linear regression equation, the $\mathrm{IC}_{50}$ obtained from the maceration sample is $11.48336 \mu \mathrm{g} / \mathrm{mL}$ and $9.81512 \mu \mathrm{g} / \mathrm{mL}$ from the UAE sample. The higher $\mathrm{IC}_{50}$ value from the UAE extraction 
Table 1: The yield extract of Kjellbergiodendron celebicum (Koord.) Merr. Leaves.

\begin{tabular}{cc}
\hline Method & \% Rendement \\
\hline Maceration & 9,253 \\
UAE & 12,380 \\
\hline
\end{tabular}

Table 2: Percentage inhibition of quercetin.

\begin{tabular}{cc}
\hline $\begin{array}{c}\text { Final Concentration } \\
(\mu \mathrm{g} / \mathrm{mL})\end{array}$ & \%Inhibition \\
\hline 1 & 18,8679245 \\
2 & 31,0796646 \\
3 & 53,6163522 \\
4 & 67,2955975 \\
5 & 81,0796646 \\
\hline
\end{tabular}

Table 3: Percentage inhibition of maceration and UAE extract.

\begin{tabular}{ccc}
\hline Final & \multicolumn{2}{c}{ \%Inhibition } \\
\cline { 2 - 3 } $\begin{array}{c}\text { Concentration } \\
(\mu \mathrm{g} / \mathrm{mL})\end{array}$ & Maceration & UAE \\
\hline 6 & 28,1872972 & 24,5233399 \\
8 & 37,8303199 & 37,8698225 \\
10 & 43,1154381 & 53,9776463 \\
12 & 53,7320352 & 64,8915187 \\
14 & 58,646268 & 74,6219592 \\
\hline
\end{tabular}

method than the maceration extraction method may be related to the total phenolic content in each extract, which will be discussed further in the next section.

\section{Quantitative antioxidant activity test with the FRAP assay}

The FRAP method is a method of testing antioxidant activity through the ability of antioxidant compounds to reduce $\mathrm{Fe}^{3+}$ ions to $\mathrm{Fe}^{2+}$ in the presence of 2.4,6-tri (2-pyridyl)-s-triazine (TPTZ) in an acidic atmosphere which produces intensive blue colour from the $\mathrm{Fe}^{2+}$-TPTZ complex and causes an increase in absorbance when measured using a microplate reader at a maximum absorption of $593 \mathrm{~nm}$. In the test using the FRAP method, ammonium ferrous sulphate (AFS) was used as a standard. First, the standard ammonium ferrous sulphate (AFS) calibration curve was made. The antioxidant activity was measured based on the sample equality with the AFS standard. The linear regression equation of AFS obtained was $y=7.211 .8 x+0.0272$ with a correlation coefficient $(r)=0.99624$

The maceration and UAE extractions of Kjellbergiodendron celebicum (Koord.) Merr. leaves were carried out using a concentration of 0.04 $\mathrm{gr} / \mathrm{L}$, and the final concentration in the well was $0.002667 \mathrm{gr} / \mathrm{L}$. The average calculation of FeEAC samples from the maceration extraction was $1,581.6 \mu \mathrm{mol} / \mathrm{gr}$ and the sample from the UAE extraction was 1.661.3 $\mu \mathrm{mol} / \mathrm{gr}$. The FeEAC value from the UAE method extraction, which was higher than the maceration extract method, may be related to the total phenolic content in each extract, which will be discussed further in the next section.

\section{Antibacterial test with the paper disc diffusion method}

The antibacterial activity test using the paper disc diffusion method was based on the principle that antimicrobial agents diffuse into the agar and inhibit the growth of microorganisms tested, and then the diameter of inhibition area is measured. ${ }^{9}$

The average measurement of the zone inhibition of the maceration and UAE extraction methods for the three microbial assays are presented in Table 4 and Figure 2. Tests were also carried out using positive control of chloramphenicol with a concentration of $30 \mu \mathrm{g} / \mathrm{mL}$ and $5 \%$ DMSO solvent as a negative control.

\section{Antibacterial test with the microdilution method}

A determination of the Minimum Inhibitory Level (MIC) by the microdilution technique was carried out by diluting the test solution serially on the microplate. The concentrations made were $3.125 ; 1,562.5$; $781.25 ; 390.6$; and $195.3 \mu \mathrm{g} / \mathrm{mL}$. A positive control of chloramphenicol with a concentration of $30 \mu \mathrm{g} / \mathrm{mL}$ was also determinate. MIC values were determined based on the turbidity measurements which were based on the Optical Density (OD) at $600 \mathrm{~nm}$ wavelength which approached the OD measurement results from the chloramphenicol control, assuming that at certain concentrations where the OD values of the test samples were similar to the antibiotics in the test samples which had inhibitory activity against bacterial growth. The MIC data for each microbe are in Table 5. From the MIC data, the extract from the UAE method shows a lower MIC value than the maceration method. This may relate to the total phenolic content present in each extract, which will be discussed further in the next section.

\section{Phytochemical screening}

The results of identification can be seen in Table 6 .

\section{Total phenolic content determination}

Polyphenol compounds have the potential as good antioxidants and antibacterial. Therefore, the determination of total phenolic compounds is important. The measurement of total phenolic content in leaf extract of Kjellbergiodendron celebicum (Koord.) Merr. was performed using the Folin-Ciocalteu method with a microplate reader. The FolinCiocalteu method works based on the principle of the tungstatemolybdate complex which is reduced by phenolic compounds,

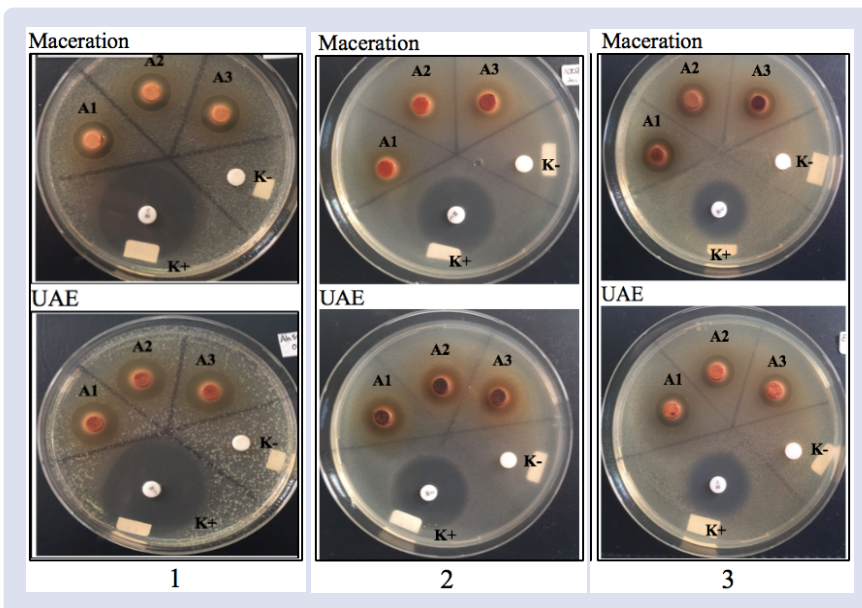

Figure 2: Paper disc diffusion method 1: Aeromonas hydrophila; 2 Edwardsiella ictaluri; 3: Flavobacterium columnare. * Description: measurement of diameter of the inhibition area includes paper disc diameter $(6 \mathrm{~mm})$.

Table 4: Average zone inhibition measurement of maceration and UAE extract.

\begin{tabular}{cccc}
\hline \multirow{2}{*}{ Sample } & \multicolumn{3}{c}{ Average zone inhibition measurement (mm) } \\
\cline { 2 - 4 } & $\begin{array}{c}\text { Aeromonas } \\
\text { hydrophila }\end{array}$ & $\begin{array}{c}\text { Edwardsiella } \\
\text { ictaluri }\end{array}$ & $\begin{array}{c}\text { Flavobacterium } \\
\text { columnare }\end{array}$ \\
\hline $\begin{array}{c}\text { Chloramphenicol } \\
30 \mu \mathrm{g} / \mathrm{mL}\end{array}$ & 27 & 55 & 18 \\
DMSO 5\% & - & - & - \\
$\begin{array}{c}\text { Maceration } \\
\text { method }\end{array}$ & 14 & 9,7 & 13,3 \\
UAE method & 17,3 & 10,7 & 13,8 \\
\hline
\end{tabular}


forming a blue complex that increases absorbance and can be detected spectrophotometry at a wavelength of $750 \mathrm{~nm} \cdot{ }^{10}$ The total phenolic content is then expressed in GAE (Gallic Acid Equivalent), which is the amount of equivalence of milligrams of gallic acid contained in 1 gram of the sample (extract) tested.

From the absorption measurements of gallic acid, a linear regression equation $y=0.2038+0.066 x$ and the correlation coefficient $(r)$ of 0.996544 were obtained. The results of the gallic acid calibration curve are shown in Figure 3. Leaf extract of Kjellbergiodendron celebicum (Koord.) Merr. from the maceration and UAE extraction methods was then examined by the same method as the gallic acid standard. Based on the results of the tests, it shows that the maceration extract contained 224.84 mgEAG/gr extract, while the UAE extracts contained $313.57 \mathrm{mgEAG} / \mathrm{gr}$ extract.

The UAE yield extract containing 313.57 mgGAE per gram of extract gave a stronger antioxidant activity than the maceration extract with 224.84 mgGAE per gram of extract. The $\mathrm{IC}_{50}$ value of the maceration sample obtained in the DPPH antioxidant activity test was $11.48336 \mu \mathrm{g} /$ $\mathrm{mL}$, whereas from the UAE sample it was $9.81512 \mu \mathrm{g} / \mathrm{mL}$. The smaller the $\mathrm{IC}_{50}$ value of a sample was, the stronger the antioxidant activity became. In the antioxidant activity test using the FRAP method, extracts from the UAE method also had a higher reduction capacity than the macerated extracts with samples from the UAE extracts which were $1.661,3 \mu \mathrm{mol} / \mathrm{gr}$, and $1.581,6 \mu \mathrm{mol} / \mathrm{gr}$ FeEAC from macerated extracts.

In the antibacterial test of the paper disc diffusion method against Aeromonas hydrophila, Edwardsiella ictaluri, and Flavobacterium columnare, the average diameter of the inhibition zone obtained from the UAE method extract was greater than the one from the maceration method extract. The MIC from the UAE method extract was also smaller than the MIC from the maceration method. The UAE extraction method is one of the modern extraction methods recommended for extracting polyphenol compounds. In previous studies, the UAE method had the ability to extract polyphenol components better than the conventional methods such as maceration ${ }^{7}$. However, to extract

\section{Table 5: Average MIC of each bacterial tested.}

\begin{tabular}{cccccc} 
& \multicolumn{3}{c}{ Extraction Method } & & Chloramphenicol $(30 \mu \mathrm{g} / \mathrm{mL})$ \\
\cline { 2 - 5 } Bacterial Name & \multicolumn{2}{c}{ Maceration } & UAE & Average \\
& Average OD & MIC $(\mu \mathrm{g} / \mathrm{mL})$ & 0,833 & $\begin{array}{c}\text { MIC } \\
(\mu \mathrm{g} / \mathrm{mL})\end{array}$ & Average OD \\
\hline Aeromonas hydrophila & 0,879 & 781,25 & 0,442 & 390,6 & 0,818 \\
Edwardsiella ictaluri & 0,401 & 781,25 & 0,413 & 390,6 & 0,463 \\
Flavobacterium columnare & 0,514 & 781,25 & & 0,486 \\
\hline
\end{tabular}

\section{Table 6: Phytochemical screening result.}

\begin{tabular}{|c|c|c|c|}
\hline Compound & Reagent & Result & Conclusion \\
\hline \multirow{3}{*}{ Alkaloid } & Bouchardat & No precipitation & $(-)$ \\
\hline & Mayer & No precipitation & $(-)$ \\
\hline & Dragendorff & No precipitation & $(-)$ \\
\hline \multirow{2}{*}{ Tannin } & Gelatin $10 \%$ & Precipitation formed & $(+)$ \\
\hline & $\mathrm{FeCl}_{3}$ & Green & $(+)$ \\
\hline \multirow[t]{2}{*}{ Saponin } & Hot water $+\mathrm{HCl}$ & Froth formed & $(+)$ \\
\hline & $\mathrm{UV} \& \mathrm{AlCl}_{3}$ & Yellow-green fluorescence & $(+)$ \\
\hline \multirow[t]{2}{*}{ Flavonoid } & $\mathrm{HCl}+\mathrm{Mg}$ & Red & $(+)$ \\
\hline & $\mathrm{HCl}+\mathrm{Zn}$ & Red & $(+)$ \\
\hline Terpenoid & Liebermann-Burchard & Green & $(+)$ \\
\hline Anthraquinon & Sulfuric acid + Benzene $+\mathrm{NaOH}$ & Red layer & $(+)$ \\
\hline \multirow{2}{*}{ Glycoside } & Anhydrous acetic acid \& sulfuric acid & Purple ring & $(+)$ \\
\hline & Molisch & Green & $(+)$ \\
\hline
\end{tabular}

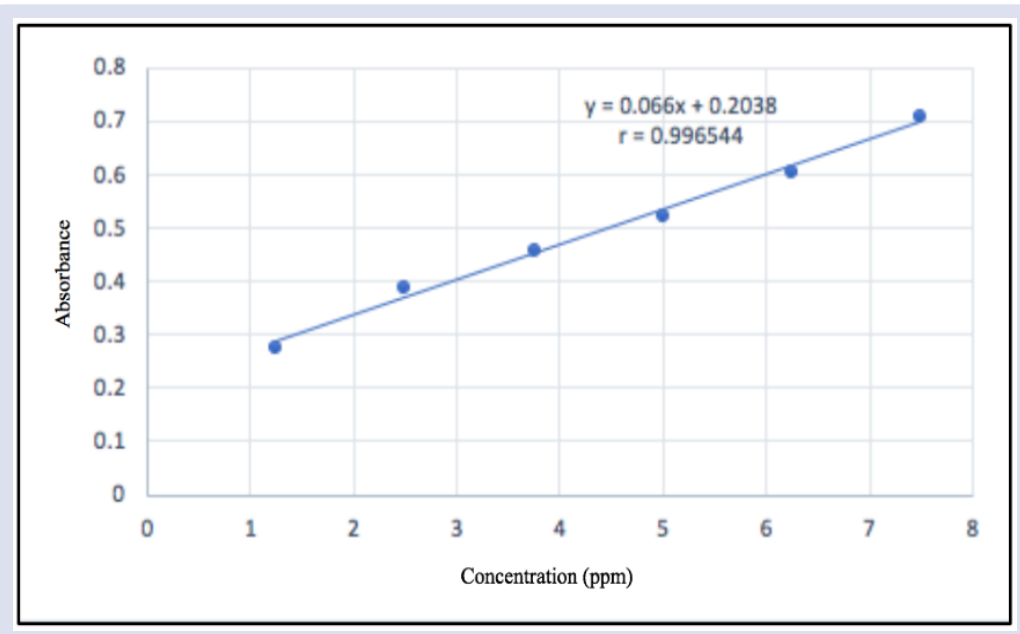

Figure 3: Gallic acid calibration curve. 
polyphenol compounds using the UAE method, we must pay attention to several factors, such as solvents, frequencies used, and temperature at extraction.

\section{CONCLUSION}

$70 \%$ ethanol leaf extract of Kjellbergiodendron celebicum (Koord.) Merr. which has the highest activity based on the DPPH and FRAP tests is an extract from the UAE extraction with $\mathrm{IC}_{50}$ value of $9.81512 \mu \mathrm{g} / \mathrm{mL}$ and FeEAC value of $1.661,3 \mu \mathrm{mol} / \mathrm{gr}$. The UAE method also has a higher potential as antibacterial activity based on the diffusion method of paper discs and microdilution with the MIC obtained $390.6 \mu \mathrm{g} / \mathrm{mL}$. The UAE extraction method is better at scanning polyphenol compounds compared to conventional maceration extraction methods. Therefore, the results of the antioxidant and antibacterial activity of the UAE method are better than those of the maceration method. Leaf extract of Kjellbergiodendron celebicum (Koord.) Merr has strong antioxidant activity and has strong antibacterial activity against fish pathogenic bacteria Aeromonas hydrophila, Edwardsiella ictaluri, Flavobacterium columnare.

\section{ACKNOWLEDGEMENTS}

The authors are very grateful for the research grand opportunity and funding provided by the Ministry of Research, Technology, and Higher Education of the Republic of Indonesia, Dr. Media Fitri Isma Nugraha, Insinas Grand Research Program in 2018 - 2019. We also thank Dr. Alias Radjamuddin from Pangkep State Polytechnic of Agriculture South Sulawesi, Prof (Ris). Dr. Andi Akhmad Mustafa, Dr. Andi Parenrengi, and the members of the Research Institute for Brackish water Aquaculture and Fisheries (BRPBAP3) Maros for all the support given during the survey in South Sulawesi. We are very thanks to Dr. Idil Ardi chef of Indonesian Research Institute for Ornamental Fish Culture - the Ministry Marine and Fisheries. We extend our sincere thanks to the Indonesian Research Institute for Ornamental Fish Culture - the Ministry Marine and Fisheries and Laboratory of Pharmacognosy, of the Faculty of Pharmacy of Universitas Indonesia for providing facilities.
This is publication Indonesian Research Institute for Ornamental Fish Culture - the Ministry Marine and Fisheries Republic Indonesia 2020-01.

\section{CONFLICTS OF INTEREST}

The authors declare that there are no conflicts of interest in this study.

\section{REFERENCES}

1. Sevcikova M, Modra H, Slaninova A, Svobodova Z. Metals as a cause of oxidative stress in fish: a review. Veterinární Medicína. 2011;56(11):537-46.

2. Livingstone DR. Oxidative stress in aquatic organisms in relation to pollution and aquaculture. Revue Méd Vét. 2003;4.

3. Csepregi K, Neugart S, Schreiner M, Hideg É. Comparative evaluation of total antioxidant capacities of plant polyphenols. Molecules. 2016;21(2):208.

4. Rugayah, Sunarti S, Sulistiarini D, Hidayat A, Rahayu M. Daftar Jenis Tumbuhan di pulau Wawonii, Sulawesi Tenggara. Lipi Press Jakarta. 2005;32.

5. Bobo-García G, Davidov-Pardo G, Arroqui C, Vírseda P, Marín-Arroyo MR Navarro M. Intra-laboratory validation of microplate methods for total phenolic content and antioxidant activity on polyphenolic extracts, and comparison with conventional spectrophotometric methods: Comparison of microplate and conventional methods for Folin- Ciocalteu and DPPH. Journal of the Science of Food and Agriculture. 2015;95(1):204-9.

6. Benzie IF, Strain JJ. Ferric reducing/antioxidant power assay: direct measure of total antioxidant activity of biological fluids and modified version for simultaneous measurement of total antioxidant power and ascorbic acid concentration. Methods in Enzymology. 1999;299:15-27.

7. Medina-Torres N, Ayora-Talavera T, Espinosa-Andrews $H$, Sánchez-Contreras A, Pacheco N. Ultrasound assisted extraction for the recovery of phenolic compounds from vegetable sources. Agronomy. 2017;7(3):47.

8. Muñiz-Márquez DB, Martínez-Ávila GC, Wong-Paz JE, Belmares-Cerda R, Rodríguez-Herrera R, Aguilar CN. Ultrasound-assisted extraction of phenolic compounds from Laurus nobilis L. and their antioxidant activity. Ultrasonics Sonochemistry. 2013;20(5):1149-54.

9. Balouiri M, Sadiki M, Ibnsouda SK. Methods for in vitro evaluating antimicrobia activity: A review. Journal of Pharmaceutical Analysis. 2016;6(2):71-9.

10. Magalhães LM, Segundo MA, Reis S, Lima JLFC. Methodological aspects about in vitro evaluation of antioxidant properties. Analytica Chimica Acta. 2008;613(1):1-19

\section{GRAPHICAL ABSTRACT}

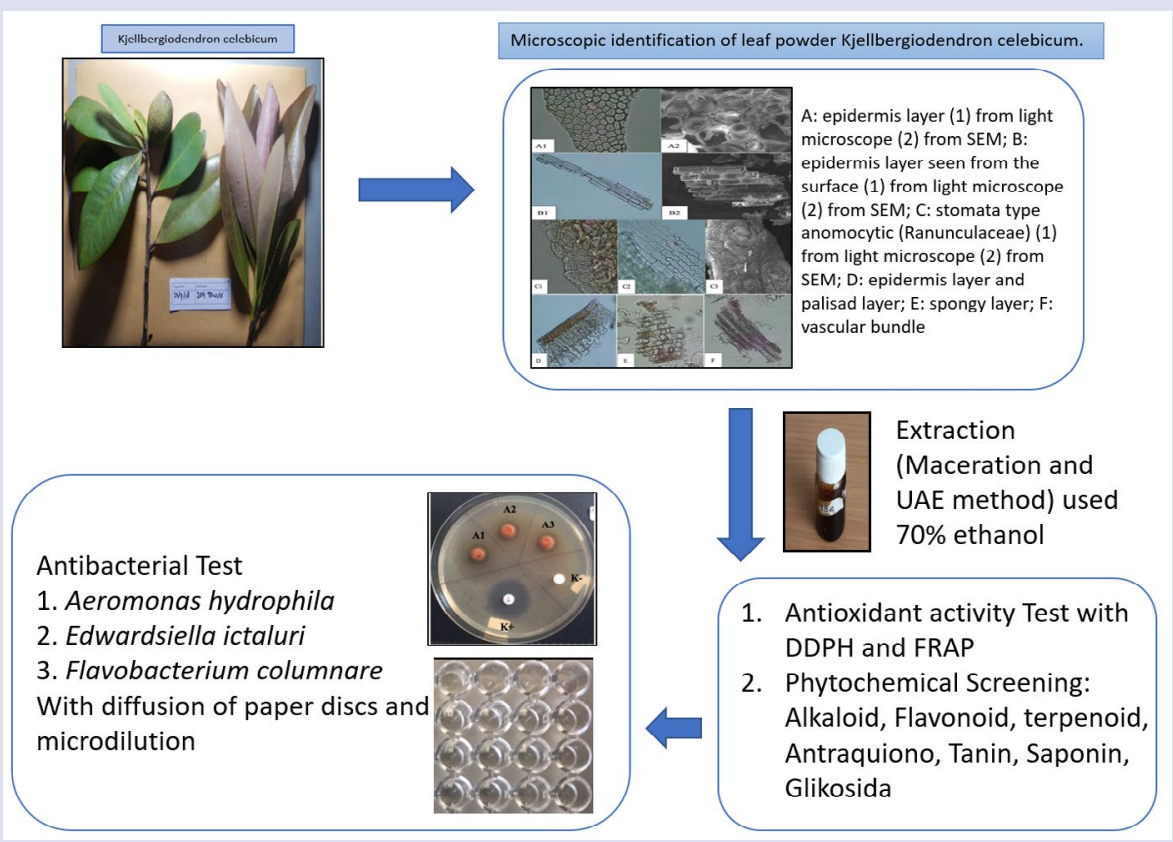




\section{ABOUT AUTHORS}

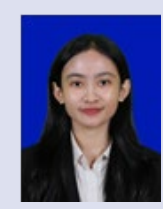

Bianca Priscilia is a bachelor degree student at the Faculty of Pharmacy, University of Indonesia. She has research experience in the field of Phytochemistry and Pharmacology.

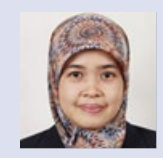

Media Fitri Isma Nugraha is a researcher at the Indonesian Institute for Ornamental Fish Culture of the Ministry Marine and Fisheries of the Republic of Indonesia. Her research Her interest includes studies in genetics, molecular biology, plant tissue culture, and allelochemical compound of aquatic-plant materials.

Hessy Novita is a young researcher in the field of microbiology and molecular biology at the Fish Disease Control Research Installation-Fisheries Research Center for Freshwater Aquaculture-Fisheries Counselling.

Berna Elya is a Professor and Lecturer at the Faculty of Pharmacy, University of Indonesia. She develops works in the area of Pharmacognosy, Phytochemistry, and Natural Material Chemistry.

Cite this article: Priscilia B, Nugraha MFI, Novita H, Elya B. Antioxidant and Antibacterial Assay Against Fish Pathogen Bacteria of Kjellbergiodendron celebicum (Koord.) Merr. Leaf Extract. Pharmacog J. 2020;12(1):173-9. 